\title{
A PROPOSAL TO EXPAND TOURISM REVENUES TO LOCALS; CITY ACTIVITY PLAN AND THE SAMPLE OF ERZURUM
}

\author{
Süleyman Toy ${ }^{1}$ \\ Uğur Çalişkan ${ }^{2}$
}

\begin{abstract}
Through an accurate decision for planning, investment and promotion, tourism can affect positively, directly, rapidly and sustainably the socioeconomic development of a nation, region, province and local destination. In order to achieve national tourism targets not only in the number tourists but also in revenue, activities are needed to lengthen stay periods and increase revenues. Such activates are only possible through mainly the touristic products attracting and integrating with all tourism types and presenting local and native cultural elements, emphasizing uniqueness and accurateness. Such activities may increase tourist satisfaction, the share locals get from revenues, the adoption rate of tourism by locals and their pleasure. Erzurum has faced in recent years some slight increase in the number pf tourist due to various types of tourism potentials e.g. winter, history - culture, nature - adventure and health and well - being. Nearly 50 thousand foreign and 340 thousand domestic tourists visit the city staying only one or two days. In order to increase the contribution of tourists to the city, length of their stay should be increased. Therefore, preparation and implementation of a city activity plan through the participation of all local actors including mainly municipalities. Maybe, only a simple plan involving pilot activities is planned. As in all parts of Anatolia, Erzurum city shelters several values to serve as touristic products. Local authorities and responsible institutions should work together in a coordination and try to implement the activity plan in a great care.
\end{abstract}

Key words: tourism revenue, event, Erzurum

\section{INTRODUCTION}

As a sector which can be defined to be all the activities performed in the travels with the aim of work, entertainment and refreshment, tourism may affect directly, quickly and sustainably the socioeconomic development across a country, region, city of a specific destination based on a true planning, accurate investment decisions, and promotion efforts. There are some prerequisites for tourism to exhibit such affirmative effects. Most important of them may be the existence of source values like natural, cultural, geographical and climatic potentials enabling certain types tourism and aftermath, the acceptance/adoption of tourism by locals who are the human resources for the sector in a specific touristic place (i.e. targeted masses affecting or affected by tourism activities). Tourism is not purely the whole of social, economic or cultural fact or activities. It is much more an occupation involving contact points with social and applied sciences as in every field which humans actively practice. From this point of

\footnotetext{
${ }^{1}$ Associate Professor, Department of City and Regional Planning, Faculty of Architecture and Design, Atatürk University 252040Erzurum, Turkey.

${ }^{2}$ Assistant Proffessor, Tourism Faculty, Muğla Sitkı Koçman University, Muğla, Turkey
} 
view, adoption of tourism by locals in an area and their expectation of employment, income and a future prospect from the sector cannot be evaluated in a one-sided approach. The fact that people construct a life on tourism sector by earning an income or work in the sector is the main reason for their adoption of the sector or its values however, to the cultural aspect, factors such as self - fulfilment, interaction and flicking may be the main reasons for their adoption of the sector as well as pleasure from success in their job. Therefore, human factor, one of the most important elements in tourism,in especially local destinations, should absolutely be involved in the sector to adopt it in not only commercial ways but also by making them a part of the sector.

From the side of tourists, they try to follow and catch changing profiles, have new demands, desire to see the unseen and taste untasted, experience the locality and swim in numerous trends. What is valid all the time is that tourists are interested in local tastes, tissues and real human stories of the areas where they visit. They always wish to return back from their journeys with the traces and memories of local blowsthey face on their holidays. When they don't gain such beautiful experiences, what happens is the purposive trips where it is impossible to mention about pleasure and tastes. For instance, a 5- day ski - resort hotel away from city centre or locals does not involve local pleasure for tourists in addition it has serious opponents from local base.

In tourism sector, Turkey accessed its targeted aims for 2023 designed in 2007 earlier than expected and revised them by changing the talks on the sector announcing quality touristic revenues in its $10^{\text {th }}$ National Development Plan. Such an approach shows that Turkey should put its everything not used for touristic purposes into service of tourism sector in addition to present practises. In this respect, every potential, including east and southeast of the country, human resources and nature should be employed to develop the sector. From also this perspective, human resource and their adoption of tourism are main prerequisites.

\section{PRESENT SITUATION OF TOURISM IN ERZURUM}

Because Erzurum has a deep historical background and bears the traces of such a history as grief and pain in close time it has huge potential for history and cultural heritage tourism. It is among the cities founded at the highest elevation in Turkey (according to the elevations of meteorological stations in the city centre, Erzurum, Ardahan, Kars, Van and Ağrı are at 1860m, 1829m, 1775m, Van 1671 and Ağrı 1632m, respectively. Such a situation gives Erzurum potential of serving as high attitude sportive camping. Due to its unique geography, untouched nature and rich water reserves (at the beginning of Çoruh, Euphrates and Aras rivers), Erzurum serves for the nature - adventure and eco - agro tourism. The city has attracted a serious amount of investment for the last years on health care sector and hospitals, it has also thermal water reserve and is close to the eastern neighbours of Turkey both geographically and culturally based on these facts the city has also potential for medical and thermal 
tourism. The city has a completed infrastructure for winter tourism in especially accommodation this potential can also be used for congress tourism (KUDAKA 2011). The largest number of tourists across the city come to winter sport facilities. Length of stays is nearly 1 to 2 days. Mainly domestic tourists prefer the area and the rate of foreign tourists is relatively small (Table 1). The number of touristic operation licensed accommodation facilities is 11 (Table 2).

Table 1. Tourist statistics in operational and municipality certificated facilities in Erzurum (KTB 2014)

\begin{tabular}{|c|c|c|c|c|c|c|c|c|c|c|c|c|}
\hline \multirow[t]{2}{*}{$\begin{array}{l}\text { Municipality } \\
\text { Licensed }\end{array}$} & \multicolumn{3}{|c|}{ Incoming number } & \multicolumn{3}{|c|}{ Overnight } & \multicolumn{3}{|c|}{ Mean overnight } & \multicolumn{3}{|c|}{ Occupation rate $(\%)$} \\
\hline & Foreign & Domestic & Total & Foreign & Domestic & Total & Foreign & Domestic & Total & Foreign & Domestic & Total \\
\hline Hinis & 49 & 4627 & 4676 & 60 & 4713 & 4773 & 1.2 & 1.0 & 1.0 & 0.59 & 46.12 & 46.70 \\
\hline Horasan & 565 & 7701 & 8266 & 648 & 8062 & 8710 & 1.1 & 1.0 & 1.1 & 1.61 & 20.08 & 21.69 \\
\hline İspir & 45 & 7435 & 7480 & 45 & 7435 & 7480 & 1.0 & 1.0 & 1.0 & 0.15 & 24.49 & 24.64 \\
\hline Köprüköy & 4 & 2390 & 2394 & 4 & 3555 & 3559 & 1.0 & 1.5 & 1.5 & 0.03 & 25.76 & 25.79 \\
\hline Oltu & 2397 & 18983 & 21380 & 2839 & 22099 & 24938 & 1.2 & 1.2 & 1.2 & 3.70 & 28.83 & 32.53 \\
\hline Pasinler & 127 & 12149 & 12276 & 204 & 23772 & 23976 & 1.6 & 2.0 & 2.0 & 0.27 & 31.26 & 31.53 \\
\hline $\begin{array}{l}\text { Aziziye } \\
\text { (Ilica) }\end{array}$ & 9 & 2574 & 2583 & 18 & 2757 & 2775 & 2.0 & 1.1 & 1.1 & 0.05 & 8.21 & 8.26 \\
\hline Yakutiye & 19632 & 128916 & 148548 & 27346 & 152891 & 180237 & 1.4 & 1.2 & 1.2 & 3.92 & 21.94 & 25.87 \\
\hline Total & 22828 & 184775 & 207603 & 31164 & 225284 & 256448 & 1.4 & 1.2 & 1.2 & 3.19 & 23.05 & 26.23 \\
\hline $\begin{array}{l}\text { Operation } \\
\text { Licensed } \\
\end{array}$ & Foreign & Domestic & Total & Foreign & Domestic & Total & Foreign & Domestic & Total & Foreign & Domestic & Total \\
\hline Oltu & 36 & 315 & 351 & 58 & 459 & 517 & 1.6 & 1.5 & 1.5 & 1.64 & 12.97 & 14.61 \\
\hline Yakutiye & 4444 & 49730 & 54174 & 6537 & 61327 & 67864 & 1.5 & 1.2 & 1.3 & 2.67 & 25.08 & 27.76 \\
\hline Palandöken & 23760 & 106389 & 130149 & 57986 & 189631 & 247617 & 2.4 & 1.8 & 1.9 & 9.65 & 31.56 & 41.22 \\
\hline Total & 28240 & 156434 & 184674 & 64581 & 251417 & 315998 & 2.3 & 1.6 & 1.7 & 7.61 & 29.62 & 37.23 \\
\hline Overall total & 51068 & 341209 & 392277 & 95745 & 476701 & 572446 & 2 & 1 & 1 & 5 & 26 & 32 \\
\hline
\end{tabular}

Table 2.The number of touristic accommodation facilities in Erzurum

\begin{tabular}{|l|c|c|c|c|c|c|c|c|c|c|c|}
\hline \multicolumn{3}{|c|}{$\begin{array}{l}\text { Operation Licensed } \\
(2009)\end{array}$} & \multicolumn{3}{c|}{$\begin{array}{c}\text { Municipality Licensed } \\
(2010)\end{array}$} & \multicolumn{3}{c|}{ Total } & \multicolumn{3}{c|}{ Investment licensed } \\
\hline $\begin{array}{l}\text { Facilitie } \\
\text { s }\end{array}$ & $\begin{array}{l}\text { Room } \\
\text { s }\end{array}$ & Beds & Facilities & Rooms & Beds & $\begin{array}{l}\text { Facilitie } \\
\text { s }\end{array}$ & $\begin{array}{l}\text { Room } \\
\text { s }\end{array}$ & Beds & $\begin{array}{l}\text { Facilitie } \\
\text { s }\end{array}$ & $\begin{array}{l}\text { Room } \\
\text { s }\end{array}$ & Beds \\
\hline $11^{*}$ & 933 & $\begin{array}{c}1 \\
941\end{array}$ & 64 & 1428 & 2881 & 75 & 3360 & $\begin{array}{c}7 \\
078\end{array}$ & 6 & 999 & $\begin{array}{l}2 \\
256\end{array}$ \\
\hline
\end{tabular}

An practice does not exist in Erzurum to increase the present touristic movement, make joints between active tourism types, rise overnight time, raise tourist satisfaction, present local tastes, expand touristic revenues to locals, contribute to the adoption of tourism by locals, change the view of locals for tourism and tourist all of which enable locals to make income from tourism and promote their culture by transferring visitors pleasure through the local touristic activities, attraction centres, service presentation focuses, production and sale sites of local products. Based on such problems, one of the suggestions to be performed may be the preparation and implementation of city activity plan. 


\section{ERZURUM CITY EVENT PLAN}

Touristic events and planning them are evaluated under different expertise. However, a well - set up event and activity plan has the functions of coming together tourists and locals. Since only a schedule offering regular, incessant and quality activities also reflecting local culture by not exaggerating and based on true stories can serve tourism, through such activities, views of both locals and tourists can be changed to positive.

It can be seen by taking into consideration the facts mentioned all above that it a requirement to share roles among local actors including private sector to constitute a collaborative transitional structure in Erzurum by determining and deciding the lists of activities to be performed in fixed time and place. Beginning from municipalities, NGOs, private sector and related governmental institutions, a top-roof structure may be formed in the coordination of locals to prepare activities and then they should be applied by sharing duties on monthly, seasonally and annually bases. Their promotion should be done with great care. Program should strictly be followed and implemented.

\section{A PROPOSAL ACTIVITY PROGRAM FOR ERZURUM}

A proposal activity plan in Erzurum may include 3 main groups, i.e. sportive, cultural and artistic. Sportive activities may include winter sport activities in the venues constructed for UNIVERSIADE (ice hockey, ski jumping towers, ice skating and curling etc.), javelin throwing on horse, nature sensitive sports etc.In terms of cultural activities, intangible cultural heritage examples can be exhibited resulting from a deep cultural tradition in the city, Dadaş culture, which has several unique ceremonies such as weddings and some others before weeding for men and women, child games and folk dances, mehter performance, religious rituals and preparation of various dishes.From artistic point of view, ice statues, Oltu stone ornamenting, local singing (aşık, poets) can be included in the program. After the determination of activities and responsible institutions, a strict activity plan should be scheduled and promoted through effective tools, like social media and city billboards by updating every detail. In addition, all the institutions in the city should announce the program through their internet sites. Preparation of booklets is another method to enlarge the promotional effect since annual program is fixed. After all, tour guides, operators and local facilities should be delivered programs and booklets to drive tourists to these activities. Maybe, the first year of this activity plan is implemented through a grant project to be financed by various sources and then the program should be continued by local organisations with great care. In the long run, all the activities should be implemented by local private sector representatives and the role of governmental institutions should be reduced. 
Table 3. An event plan sample

\begin{tabular}{|c|c|c|c|c|c|c|c|c|}
\hline & Mon. & Tue. & Wed. & Thu. & Fri. & Sat. & Sun. & Responsible \\
\hline $\begin{array}{l}10: 00 \\
12: 00\end{array}$ & $\begin{array}{l}\text { Child } \\
\text { Games } \\
\text { (bone) }\end{array}$ & $\begin{array}{l}\text { Child } \\
\text { Games } \\
\text { (circle) }\end{array}$ & Ice Skating & $\begin{array}{c}\text { Ski } \\
\text { Jumping }\end{array}$ & Curling & $\begin{array}{c}\text { Ice } \\
\text { Hockey }\end{array}$ & Ice Skating & $\begin{array}{c}\text { Youth } \\
\text { Services and } \\
\text { Sport } \\
\text { Management }\end{array}$ \\
\hline \multicolumn{9}{|l|}{ 13:00 } \\
\hline $\begin{array}{l}14: 00 \\
16: 00\end{array}$ & Folk dances & $\begin{array}{l}\text { Sufi Music; } \\
\text { (Gazelle } \\
\text { Tasavvuf } \\
\text { Dhikr) }\end{array}$ & $\begin{array}{c}\text { Turkish } \\
\text { Night } \\
\text { (Mehter } \\
\text { Band, } \\
\text { Caucasian } \\
\text { Dances) } \\
\end{array}$ & $\begin{array}{c}\text { Folk } \\
\text { dances }\end{array}$ & $\begin{array}{c}\text { Sufi } \\
\text { Music; } \\
\text { (Gazelle } \\
\text { Tasavvuf } \\
\text { Dhikr) }\end{array}$ & $\begin{array}{c}\text { Folk } \\
\text { dances }\end{array}$ & $\begin{array}{c}\text { Turkish } \\
\text { Night } \\
\text { (Mehter } \\
\text { Band, } \\
\text { Caucasian } \\
\text { Dances) } \\
\end{array}$ & $\begin{array}{c}\text { Public } \\
\text { Education } \\
\text { Centres, } \\
\text { Grand } \\
\text { Municipality } \\
\text { Private sector }\end{array}$ \\
\hline \multicolumn{9}{|l|}{ 17:00 } \\
\hline $\begin{array}{l}19: 00 \\
20: 00\end{array}$ & $\begin{array}{c}\text { Traditional } \\
\text { wedding } \\
\text { ceremony } \\
\text { for women }\end{array}$ & $\begin{array}{l}\text { Traditional } \\
\text { wedding } \\
\text { ceremony } \\
\text { for men }\end{array}$ & $\begin{array}{c}\text { A local } \\
\text { hero tales } \\
\text { (Teyo } \\
\text { Pehlivan) }\end{array}$ & $\begin{array}{l}\text { Aşıklar } \\
\text { Night } \\
\text { Poets }\end{array}$ & $\begin{array}{c}\text { Erzurum } \\
\text { folk songs } \\
\text { choir }\end{array}$ & $\begin{array}{c}\text { Sketches } \\
\text { in Local } \\
\text { dialect }\end{array}$ & $\begin{array}{l}\text { Youth } \\
\text { Games }\end{array}$ & $\begin{array}{c}\text { Public } \\
\text { Education } \\
\text { Centres, } \\
\text { Grand } \\
\text { Municipality } \\
\text { Private sector }\end{array}$ \\
\hline
\end{tabular}

\section{CONCLUSION AND SUGGESTIONS}

As a conclusion, it is important to state that in order to catch the targets in national tourism strategy document for not only tourist number but also tourism revenues, the number of overnights should be increased through new activities and events which can contribute to the increases in revenues.

Such activities should attract the attentions of all tourism types and offer the opportunity to integrate with them. The activities to be set up should also carry local characteristicsand cultural features, focus on uniqueness and localityand present local touristic products. Such activities can both increase tourist satisfaction and the share of locals from tourism revenues.

As the result of such an approach, local people can adopt tourism activities and tourism itself as a whole by having pleasure from their works. Through winter, history and culture, nature - adventure and medical tourism activities, Erzurum has gained some tourism revenues in recent years.

Nearly 50 thousand foreign and 340 thousand domestic tourists visit the city every year. Even though the number of tourist is not enough for the city, this potential should be utilised more effectively by increasing the number of overnights which is now nearly 1 to 2 days to contribute more to locals. In this respect, city activity plan is an important practice to be implemented beginning with simple and small number of activities. As in every part of Anatolia, Erzurum has several local source values to serve for tourism. The first things to be done for this purpose are to move local governments and responsible institutions in coordination and implement pilot activities taking place in the city activity/event plan. 


\section{REFERENCES}

1. KUDAKA (2011). Kuzeydoğu Anadolu Bölgesi Inovasyona Dayalı Bölgesel Turizm Stratejisi ve Eylem Planı. Ankara. Seyr Ajans Grafik.

2. KTB 2014. Kültür Ve Turizm Bakanlığg Konaklama İstatistikleri (Turizm İşletme ve Belediye Belgeli 2014),ISSN: 1300 - 6894 